\title{
Isobolographic Method and Invertebrate (Planarian) Model for Evaluating Combinations of Waterways Pollutants
}

\author{
Robert B. Raffa ${ }^{1 *}$, Deborah A. Gallo ${ }^{2}$, Christopher S. Tallarida ${ }^{1,3}$, Scott M. Rawls ${ }^{3}$, \\ Ronald J. Tallarida ${ }^{3}$ \\ ${ }^{1}$ Department of Pharmaceutical Sciences, Temple University School of Pharmacy, Philadelphia, USA; ${ }^{2}$ United States Public Health \\ Service, Tsehootsooi Medical Center, Fort Defiance, USA; ${ }^{3}$ Department of Pharmacology, School of Medicine, Center for Substance \\ Abuse Research, Temple University, Philadelphia, USA. \\ Email: *robert.raffa@temple.edu
}

Received July $5^{\text {th }}$, 2012; revised August $13^{\text {th }}$, 2012; accepted September $14^{\text {th }}, 2012$

\begin{abstract}
Agricultural, pharmaceutical, and other biologically active substances are emptied or leach into waterways and groundwater, where they can dose-relatedly cause pharmacologic or toxic effects on the resident or dependent animal species. Standard methods can be used to evaluate the effects of individual substances, but evaluation of combinations of substances is more difficult. The mathematically rigorous method of isobolographic analysis was coupled with a simple in vivo invertebrate model. Planarians were selected because they are the lowest extant species with a centralized nervous system. Neostigmine bromide and monopotassium phosphate $\left(\mathrm{KH}_{2} \mathrm{PO}_{4}\right)$ were selected as representative of two types of potential pollutants. Neostigmine bromide and $\mathrm{KH}_{2} \mathrm{PO}_{4}$ individually produced dose-related lethality over a 60 -minute observation period with $L D 50$ values of 122 and $70 \mathrm{mM}$, respectively. The $L D 50$ value of a 1:1 combination of the two was significantly different $(p<0.05)$ from the isobolographic line of additivity. We used planarians as a representative fresh-water species and joint-action ("isobolographic") analysis to examine possible interaction between pollutants. In the demonstrative example reported here, there was a subadditive interaction between a 1:1 fixed-ratio combination of neostigmine bromide (as a representative acetylcholinesterase inhibitor used in pesticides) and potassium phosphate (used in fertilizers and detergents).
\end{abstract}

Keywords: Combinations; Isobolographic Analysis; Methods; Pollutants; Planarians

\section{Introduction}

The extent to which active pharmaceutical ingredients (APIs) are present in aquatic environments was revealed in 2004 during the first nationwide survey of pharmaceutical compounds detected in surface waters (rivers, lakes, and marine waters), groundwater, and drinking water [1]. The problem is widespread throughout the world [2-15]. APIs can enter waterways by several routes, including excretion following therapeutic use, discharge of treated wastewater from manufacturing facilities, or disposal of unused medications [16]. Agricultural substances, detergents, and a host of other biologically active chemicals are dumped into or leach into these same waterways [5,17-29]. Unfortunately, there is very minimal amount of information regarding potential effects on human and aquatic ecosystems from exposure to combinations of APIs and other chemicals.

\footnotetext{
"Corresponding author.
}

The nature of the interaction between the components of a combination can lead to additive, sub-additive, or to supra-additive (synergistic) pharmacological or toxicological effects. A mathematically rigorous method to evaluate combinations (known as joint action analysis) has been developed and has been applied to pharmacological systems [30-40].

We report a convenient model for the measurement and quantitative assessment of the toxicity of water pollutant combinations using a fresh-water species that has a primitive nervous system, including neurotransmitter and 2nd messenger systems [41-50] and that are useful for study of drug action and physiological processes associated with drug abuse, such as physical dependence and withdrawal [51-61]. We chose for illustrative purposes of the method the combination of a representative of substances used as insecticides (an acetylcholinesterase inhibitor, neostigmine bromide) and a representative of substances used in detergents and fertilizers, potassium 
monophosphate.

\section{Materials and Methods}

\subsection{Animals and Chemicals}

The planarians (Dugesia dorotocephala) were purchased from Carolina Biological Supply Co. (Burlington, NC). They were acclimated to laboratory conditions, at room temperature $\left(21^{\circ} \mathrm{C}\right)$, and tested within $48 \mathrm{~h}$. Neostigmine bromide and potassium monophosphate $\left(\mathrm{KH}_{2} \mathrm{PO}_{4}\right)$ were obtained from commercial sources and prepared at the desired concentration in tap water.

\subsection{Testing}

Planarians were placed individually into a four-quadrant plastic Petri dish (diameter $=100 \mathrm{~mm}$ ) containing $10 \mathrm{~mL}$ of neostigmine bromide (6 doses), $\mathrm{KH}_{2} \mathrm{PO}_{4}$ (6 doses), or 1:1 combination of neostigmine bromide and $\mathrm{KH}_{2} \mathrm{PO}_{4}(6$ doses). Percent lethality at the end of a 60-min exposure was determined.

\subsection{Isobolographic Analysis}

Isobolographic analysis and pharmacologic applications have been described (for a comprehensive review, see monograph [39]). An isobolograph is a plot of dose (or concentration) pairs in the combination that produce the same effect, which is often selected as the half maximal effect (ED50 value). If drug B of combination A and B acting alone gives effect in concentration $B$, pairs $(a, b)$ are related to $b$ plus the $b$-equivalent of $a$ such that $b+$ $b_{e q}=B$. This may be written $b+a / R=B$ and rearranged to the form $b / B+a / A=1$. If substances $A$ and $B$ produce equal maximal effects, the concentration pairs $(a$, $b$ ) are points that constitute a straight line. If the experimental combination yields a result that plots as a point on this line, it is additive. If it plots as a point below the line of additivity (i.e., a lower dose of each is needed), the combination is greater than additive (synergistic). If it plots as a point below the line of additivity (i.e., a higher dose of each is needed to produce the same effect), the combination is sub-additive. Numerous studies have used the isobolographic approach [62-69]. In the illustrative example used here, constituent doses were used in fixed ratio, which allows simple determination of combination doses that produce the specified level of effect (ED50 in the example). This is accomplished by fitting dose-effect data using an appropriate regression procedure and the intersection of this line with the additive isobole gives the dose pair that is additive. It also allows quantitative assessment and statistical testing of any departure from additivity.

\subsection{Statistics}

The linear isobole of additivity, applicable in the present study because of constant relative potency, is convenient for estimating the variance of the additive total dose. All points $(a, b)$ on this line can be expressed as fractions $(f$ and $(1-f)$ ) of the respective potencies $A$ and $B$, that is, $a=$ $f A$ and $b=(1-f) B$, and thus any combination with constituent amounts chosen such that dose $B / \operatorname{dose} A=(1-f) B / f A$ has a total quantity given by $T=f A+(1-f) B$. The variance of the additive total $T$ is therefore given by $V(T)=f^{2} V(A)+(1-f)^{2} V(B)$, where $f$ and $(1-f)$ are reasonably estimated from the mean $A$ and mean $B$. The total additive variance calculated from the above allows a comparison with the experimentally determined total dose variance.

\section{Results}

\subsection{Substances Alone and in Combination}

Planarians ( $\mathrm{N}=18$ per dose) were placed individually into each of the four quadrants of the Petri dish. At $60 \mathrm{~min}$, the number of planarians dead was counted and \% lethality was determined. Neostigmine bromide by itself produced dose-related lethality $(\%$ lethality $=1617.4$ dose 146.7). The $L D 50$ value for neostigmine bromide alone was $122 \mathrm{mM}$. $\mathrm{KH}_{2} \mathrm{PO}_{4}$ also produced dose-related lethality alone (\% lethality $=1572.5$ dose -61.5$)$. The $L D 50$ value for $\mathrm{KH}_{2} \mathrm{PO}_{4}$ by itself was $70 \mathrm{mM}$. The fixed-ratio combination (1:1) of neostigmne bromide plus $\mathrm{KH}_{2} \mathrm{PO}_{4}$ produced dose-related lethality (\% lethality $=1535.2$ dose - 76.2). The $L D 50$ value for the 1:1 combination was 82 $\mathrm{mM}$. The data are plotted in Figure 1.

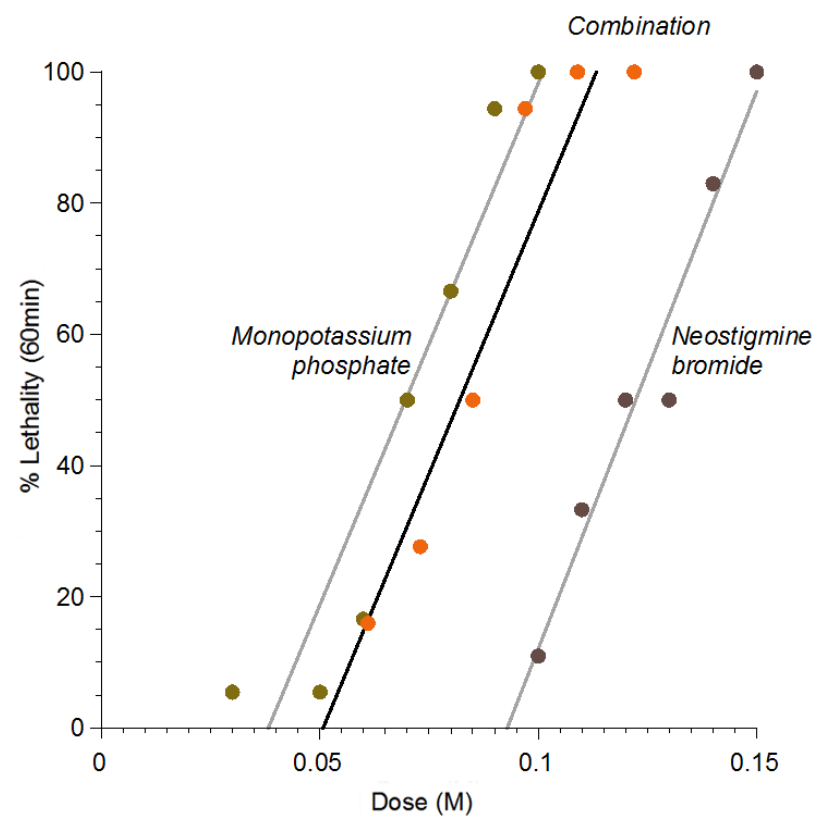

Figure 1. Dose-related lethality at 60 minutes produced by monopotassium phosphate alone, neostigmine alone, or a 1:1 combination of monopotassium phosphate plus neostigming bromide. $N=18$ planarians. 


\subsection{Isobolographic Analysis}

An isobologram was constructed using the percent lethality data and is displayed in Figure 2. The $L D 50$ value for neostigmine bromide alone (i.e., $122 \mathrm{mM}$ ) is plotted on the ordinate and the $L D 50$ value for $\mathrm{KH}_{2} \mathrm{PO}_{4}$ alone (i.e., $70 \mathrm{mM}$ ) is plotted on the abscissa. A straight line connecting the $L D 50$ values of the individual agents is the line of additivity. The $L D 50$ value of the fixed-ratio combination of neostigmine bromide plus $\mathrm{KH}_{2} \mathrm{PO}_{4}$ is plotted as the point. The $L D 50$ value of the combination is significantly ( $p<0.05$ ) above the line of additivity. This is indicative of a sub-additive interaction.

\section{Discussion}

Pharmaceutical and agricultural substances increasingly are being found in waterways in concentrations that produce deleterious biological effects [70-72]. Evaluation of the toxicity of individual substances is a common practice, however evaluation of the contribution of potential interactive effects in combinations of pollutants is increasingly being appreciated and investigated [73-77]. In combinations, the possibility of non-additive interaction arises. Thus three outcomes are possible: additive, sub-additive, and supra-additive (synergy). For the non-additive interactions, the determination of statistical significant difference from additivity requires a thorough evaluation using rigorous procedures (reviewed in [39]).

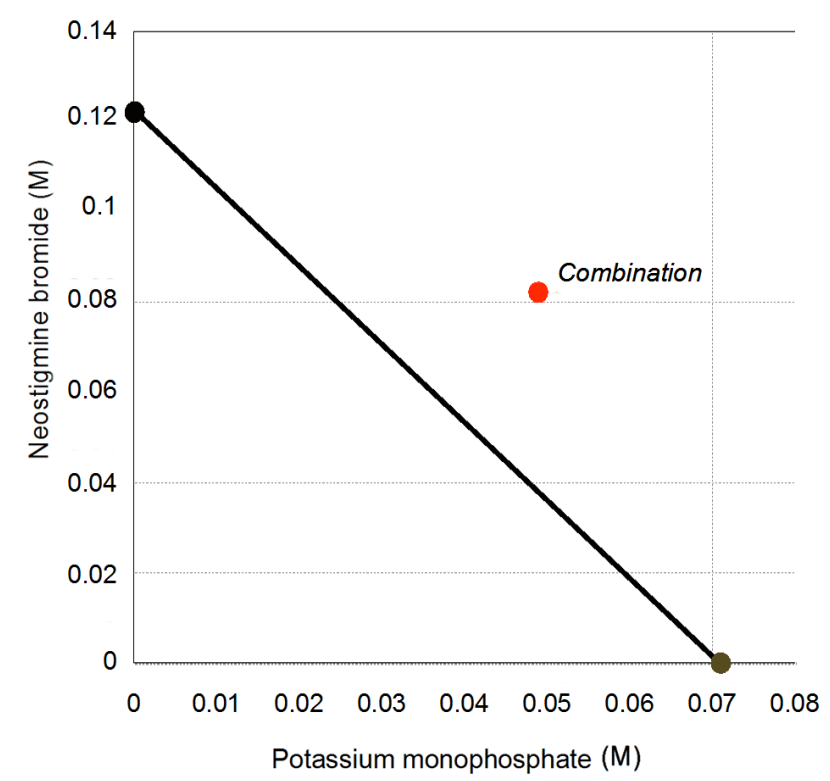

Figure 2. Isobologram of the $L D 50$ values obtained from the data shown in Figure 1. The $L D 50$ values for potassium monophosphate or neostigmine exposure alone are plotted on the ordinate and on the ordinate and abscissa. The $L D 50$ value of the combination is significantly different $(p<0.05)$ (the error bars are within the dimension of the circle) from the line of additivity.
The present work investigated the use of a simple in vivo planarian model. Planarians have a simple nervous system and mammalian-like neurotransmitter systems (e.g., $[41,48,50])$. Thus, they are the lowest form of animal that would display relevant neurotoxicity. They respond with quantifiable dose-related behavioral changes to drug exposure and withdrawal (e.g., [41,43,45,46,4951,54,57,58,61]). And receptor-mediated mechanisms can be verified using receptor-selective antagonists. We have previously used planarian models for investigating drug action and the physiological processes involved in physical dependence (for review, see monograph [55]). Like-wise, we have previously developed and used isobolographic analysis for a variety of biological endpoints (for review, see [39]).

In the present study, the two substances were selected for illustrative purposes: one (neostigmine bromide) as representative of acetylcholinesterase inhibitors, a class of substances that have been common ingredients of insecticides; the other one (potassium monophosphate) as a representative of chemicals that have been common ingredients in fertilizers and detergents. Both substances produced dose-related lethality (reaching 100\%) when they were tested alone. The dose-response curves were parallel, thus relative potency was constant throughout the range of doses. The straight-line isobole of additivity applies if and only if the relative potency is a constant, as was the case in this study.

The 1:1 fixed-ratio combination of neostigmine bromide and $\mathrm{KH}_{2} \mathrm{PO}_{4}$ produced dose-related and maximal lethality. Compared to the toxicity of exposure to the agents tested individually, the toxic effect of the combination was sub-additive. This was a surprising finding. We had anticipated an additive or possibly even synergistic interaction. Thus the importance of actually testing combinations was unintentionally emphasized. It should be noted that the demonstration of sub-additivity in the present study applies to the conditions used. It is possible that the use of other fixed-ratios would have yielded additive or supra-additive interactions. Likewise, lethality is only one adverse effect and should not be used as the only measure of safety. Multiple more subtle sub-lethal adverse effects of combinations might result from particular combinations of pollutants. Each case requires careful and rigorous evaluation. The present study offers an example of rigorous mathematical joint action analysis applied in a convenient in vivo model.

\section{Acknowledgements}

The authors thank Timothy Shickley, Ph.D., for suggesting Planaria as a model. This work was supported by NIDA grants DA15378 (RBR), DA022694 (SMR) and DA09793 (RJT). 


\section{REFERENCES}

[1] P. D. Anderson, V. J. D’Aco, P. Shanahan, S. C. Chapra M. E. Buzby, V. L. Cunningham, B. M. Duplessie, E. P. Hayes, F. J. Mastrocco, N. J. Parke, J. C. Rader, J. H. Samuelian and B. W. Schwab, "Screening Analysis of Human Pharmaceutical Compounds in US Surface Waters," Environmental Science \& Technology, Vol. 38, No. 3, 2004, pp. 838- 849. doi:10.1021/es034430b

[2] S. Mompelat, O. Thomas and B. Le Bot, "Contamination Levels of Human Pharmaceutical Compounds in French Surface and Drinking Water," Journal of Environmental Monitoring, Vol. 13, No. 10, 2011, pp. 2929-2939. doi:10.1039/c1em10335k

[3] J. L. Martinez, "Environmental Pollution by Antibiotics and by Antibiotic Resistance Determinants," Environmental Pollution, Vol. 157, No. 11, 2009, pp. 2893-2902. doi:10.1016/j.envpol.2009.05.051

[4] S. Zheng, X. Qiu, B. Chen, X. Yu, Z. Liu, G. Zhong, H. Li, M. Chen, G. Sun, H. Huang, W. Yu and D. Freestone, "Antibiotics Pollution in Jiulong River Estuary: Source, Distribution and Bacterial Resistance," Chemosphere, Vol. 84, No. 11, 2011, pp. 1677-1685. doi:10.1016/j.chemosphere.2011.04.076

[5] B. Meyer, J. Y. Pailler, C. Guignard, L. Hoffmann and A. Krein, "Concentrations of Dissolved Herbicides and Pharmaceuticals in a Small River in Luxembourg," Environmental Monitoring and Assessment, Vol. 180, No. 1-4, 2011, pp. 127-146.

[6] J. Martin, D. Camacho-Munoz, J. L. Santos, I. Aparicio and E. Alonso, "Monitoring of Pharmaceutically Active Compounds on the Guadalquivir River Basin (Spain): Occurrence and Risk Assessment," Journal of Environmental Monitoring, Vol. 13, No. 7, 2011, pp. 2042-2049. doi:10.1039/c1em10185d

[7] Q. Sui, J. Huang, S. Deng, W. Chen and G. Yu, "Seasonal Variation in the Occurrence and Removal of Pharmaceuticals and Personal Care Products in Different Biological Wastewater Treatment Processes,” Environmental Science \& Technology, Vol. 45, No. 8, 2011, pp. 33413348. doi:10.1021/es200248d

[8] S. Kleywegt, V. Pileggi, P. Yang, C. Hao, X. Zhao, C. Rocks, S. Thach, P. Cheung and B. Whitehead, "Pharmaceuticals, Hormones and Bisphenol A in Untreated Source and Finished Drinking Water in Ontario, CanadaOccurrence and Treatment Efficiency," Science of the Total Environment, Vol. 409, No. 8, 2011, pp. 1481-1488. doi:10.1016/j.scitotenv.2011.01.010

[9] D. Fatta-Kassinos, S. Meric and A. Nikolaou, "Pharmaceutical Residues in Environmental Waters and WasteWater: Current State of Knowledge and Future Research," Analytical and Bioanalytical Chemistry, Vol. 399, No. 1, 2011, pp. 251-275. doi:10.1007/s00216-010-4300-9

[10] W. J. Sim, J. W. Lee, E. S. Lee, S. K. Shin, S. R. Hwang and J. E. Oh, "Occurrence and Distribution of PharmaCeuticals in Wastewater from Households, Livestock Farms, Hospitals and Pharmaceutical Manufactures," Chemosphere, Vol. 82, No. 2, 2011, pp. 179-186. doi:10.1016/j.chemosphere.2010.10.026

[11] A. Y. Lin, X. H. Wang and C. F. Lin, "Impact of Waste-
Waters and Hospital Effluents on the Occurrence of Controlled Substances in Surface Waters," Chemosphere, Vol. 81, No. 5, 2010, pp. 562-570. doi:10.1016/j.chemosphere.2010.08.051

[12] D. G. Larsson, "Release of Active Pharmaceutical Ingredients from Manufacturing Sites-Need for New Management Strategies,” Integrated Environmental Assessment and Management, Vol. 6, No. 1, 2010, pp. 184-186. doi:10.1002/ieam.20

[13] Y. Valcarcel, S. Gonzalez Alonso, J. L. Rodriguez-Gil, A. Gil and M. Catala, "Detection of Pharmaceutically Active Compounds in the Rivers and Tap Water of the Madrid Region (Spain) and Potential Ecotoxicological Risk,” Chemosphere, Vol. 84, 10, No. 2011, pp. 1336-1348. doi:10.1016/j.chemosphere.2011.05.014

[14] M. S. Kostich, A. L. Batt, S. T. Glassmeyer and J. M. Lazorchak, "Predicting Variability of Aquatic Concentrations of Human Pharmaceuticals," Science of the Total Environment, Vol. 408, No. 20, 2010, pp. 4504-4510. doi:10.1016/j.scitotenv.2010.06.015

[15] S. Terzic, I. Senta and M. Ahel, "Illicit Drugs in WasteWater of the City of Zagreb (Croatia) -Estimation of Drug Abuse in a Transition Country," Environmental Pollution, Vol. 158, No. 8, 2010, pp. 2686-2693. doi:10.1016/j.envpol.2010.04.020

[16] T. Heberer, “Occurrence, Fate, and Removal of Pharmaceutical Residues in the Aquatic Environment: A Review of Recent Research Data,” Toxicology Letters, Vol. 131, No. 1, 2002, pp. 5-17. doi:10.1016/S0378-4274(02)00041-3

[17] A. Baba and G. Tayfur, "Groundwater Contamination and Its Effect on Health in Turkey,” Environmental Monitoring and Assessment, Vol. 183, No. 1-4, 2011, pp. 77-94. doi:10.1007/s10661-011-1907-z

[18] K. Mishra, R. C. Sharma and S. Kumar, "Contamination Levels and Spatial Distribution of Organochlorine PestiCides in Soils from India," Ecotoxicology and Environmental Safety, Vol. 76, 2012, pp. 215-225. doi:10.1016/j.ecoenv.2011.09.014

[19] T. A. Edge, A. El-Shaarawi, V. Gannon, C. Jokinen, R. Kent, I. U. Khan, W. Koning, D. Lapen, J. Miller, N. Neumann, R. Phillips, W. Robertson, H. Schreier, A. Scott, I. Shtepani, E. Topp, G. Wilkes and E. van Bochove, "Investigation of an Escherichia coli Environmental Benchmark for Waterborne Pathogens in Agricultural Watersheds in Canada,” Journal of Environmental Quality, Vol. 41, No. 1, 2012, pp. 21-30. doi:10.2134/jeq2010.0253

[20] F. Zan, S. Huo, B. Xi, J. Su, X. Li, J. Zhang and K. M. Yeager, "A 100 Year Sedimentary Record of Heavy Metal Pollution in a Shallow Eutrophic Lake, Lake Chaohu, China," Journal of Environmental Monitoring, Vol. 13, No. 10, 2011, pp. 2788-2797. doi:10.1039/c1em10385g

[21] M. H. Pham, Z. Sebesvari, B. M. Tu, H. V. Pham and F. G. Renaud, "Pesticide Pollution in Agricultural Areas of Northern Vietnam: Case Study in Hoang Liet and Minh Dai Communes," Environmental Pollution, Vol. 159, No. 12, 2011, pp. 3344-3350. doi:10.1016/j.envpol.2011.08.044 
[22] S. S. Kaushal, P. M. Groffman, L. E. Band, E. M. Elliott, C. A. Shields and C. Kendall, "Tracking Nonpoint Source Nitrogen Pollution in Human-Impacted Watersheds," Environmental Science \& Technology, Vol. 45, No. 19, 2011, pp. 8225-8232. doi:10.1021/es200779e

[23] A. E. Khater, "Uranium and Trace Elements in Phosphate Fertilizers-Saudi Arabia,” Health Physics, Vol. 102, No. 1, 2012, pp. 63-70. doi:10.1097/HP.0b013e3182289c17

[24] E. U. Cantu-Soto, M. M. Meza-Montenegro, A. I. Valenzuela-Quintanar, A. Felix-Fuentes, P. Grajeda-Cota, J. J. Balderas-Cortes, C. L. Osorio-Rosas, G. Acuna-Garcia and M. G. Aguilar-Apodaca, "Residues of Organochlorine Pesticides in Soils from the Southern Sonora, Mexico," Bulletin of Environmental Contamination and Toxicologyl, Vol. 87, No. 5, 2011, pp. 556-560. doi:10.1007/s00128-011-0353-5

[25] P. Nila Rekha, R. S. Kanwar, A. K. Nayak, C. K. Hoang and C. H Pederson "Nitrate Leaching to Shallow Groundwater Systems from Agricultural Fields with Different Management Practices,” Journal of Environmental Monitoring, Vol. 13, No. 9, 2011, pp. 2550-2558. doi:10.1039/c1em10120j

[26] S. E. Lewis, J. E. Brodie, Z. T. Bainbridge, K. W. Rohde, A. M. Davis, B. L. Masters, M. Maughan, M. J. Devlin, J. F. Mueller and B. Schaffelke, "Herbicides: A New Threat to the Great Barrier Reef," Environmental Pollution, Vol. 157, No. 8-9, 2009, pp. 2470-2484. doi:10.1016/j.envpol.2009.03.006

[27] F. Licciardello, M. L. Antoci, L. Brugaletta and G. L. Cirelli, "Evaluation of Groundwater Contamination in a Coastal Area of South-Eastern Sicily," Journal of Environmental Science and Health, Part B: Pesticides, Food Contaminants, and Agricultural Wastes, Vol. 46, No. 6, 2011, pp. 498-508.

[28] V. Babu, P. Unnikrishnan, G. Anu and S. M. Nair, "Distribution of Organophosphorus Pesticides in the bed Sediments of a Backwater System Located in an Agricultural Watershed: Influence of Seasonal Intrusion of Seawater," Archives of Environmental Contamination and Toxicology, Vol. 60, No. 4, 2011, pp. 597-609. doi:10.1007/s00244-010-9569-3

[29] S. Burgert, R. B. Schafer, K. Foit, M. Kattwinkel, L. Metzeling, R. MacEwan, B. J. Kefford and M. Liess, "Modelling Aquatic Exposure and Effects of Insecticides-Application to South-Eastern Australia," Science of the Total Environment, Vol. 409, No. 14, 2011, pp. 2807-2814. doi:10.1016/j.scitotenv.2011.02.042

[30] S. Loewe, "The Problem of Synergism and Antagonism of Combined Drugs," Arzneimittelforschung, Vol. 3, No. 6, 1953, pp. 285-290.

[31] S. Loewe, “Antagonisms and Antagonists,” Pharmacological Reviews, Vol. 9, No. 2, 1957, pp. 237-242.

[32] R. J. Tallarida, "Statistical Analysis of Drug Combinations for Synergism,” Pain, Vol. 49, No. 1, 1992, pp. 9397. doi:10.1016/0304-3959(92)90193-F

[33] R. J. Tallarida and R. B. Raffa, “Testing for Synergism over a Range of Fixed Ratio Drug Combinations: Replacing the Isobologram,” Life Sciences, Vol. 58, No. 2, 1996, pp. PL23-PL28.
[34] R. J. Tallarida, H. L. Kimmel and S. G. Holtzman, “Theory and Statistics of Detecting Synergism between Two Active Drugs: Cocaine and Buprenorphine," Psychopharmacology (Berl), Vol. 133, No. 4, 1997, pp. 378-382. doi:10.1007/s002130050417

[35] R. J. Tallarida, F. Porreca and A. Cowan, "Statistical Analysis of Drug-Drug and Site-Site Interactions with Isobolograms,” Life Sciences, Vol. 45, No. 1989, pp. 947-961. doi:10.1016/0024-3205(89)90148-3

[36] R. J. Tallarida, D. J. Stone, Jr. and R. B. Raffa, “Efficient Designs for Studying Synergistic Drug Combinations," Life Sciences, Vol. 61, No. 26, 1997, pp. PL417PL425.

[37] R. J. Tallarida, D. J. Stone Jr., J. D. McCary and R. B. Raffa, "Response Surface Analysis of Synergism between Morphine and Clonidine," Journal of Pharmacology and Experimental Therapeutics, Vol. 289, No. 1, 1999, pp. 813.

[38] R. J. Tallarida and R. B. Murray, "Manual of Pharmacologic Calculation with Computer Programs," 2nd Edition, Springer Verlag, New York, 1987.

[39] R. J. Tallarida, "Drug Synergism and Dose-Effect Data Analysis,” Chapman \& Hall/CRC Press, Boca Raton, 2000. doi:10.1201/9781420036107

[40] R. J. Tallarida, U. Midic, N. Lamarre and Z. Obradovic, "Searching for Synergism among Combinations of Drugs of Abuse and the Use of Isobolographic Analysis," arXiv: 1202.4742v1[q-bio.QM], 2012.

[41] S. Algeri, A. Carolei, P. Ferretti, C. Gallone, G. Palladini and G. Venturini, "Effects of Dopaminergic Agents on Monoamine Levels and Motor Behaviour in Planaria," Comparative Biochemistry and Physiology Part C: Comparative Pharmacology, Vol. 74, No. 1, 1983, pp. 27-29. doi:10.1016/0742-8413(83)90142-1

[42] F. R. Buttarelli, F. E. Pontieri, V. Margotta and G. Palladini, "Acetylcholine/Dopamine Interaction in Planaria," Comparative Biochemistry and Physiology-Part C: Toxicology \& Pharmacology, Vol. 125, No. 2, 2000, pp. 225231.

[43] A. Carolei, V. Margotta and G. Palladini, "Proposal of a New Model with Dopaminergic-Cholinergic Interactions for Neuropharmacological Investigations,” Neuropsychobiology, Vol. 1, No. 6, 1975, pp. 355-364. doi:10.1159/000117512

[44] G. Palladini, V. Margotta, A. Carolei, F. Chiarini, M. Del Piano, G. M. Lauro, L. Medolago-Albani and G. Venturini, "The Cerebrum of Dugesia Gonocephala s.1. Platyhelminthes, Turbellaria, Tricladida. Morphological and Functional Observations," Journal für Hirnforschung, Vol. 24, No. 2, 1983, pp. 165-172.

[45] G. Palladini, S. Ruggeri, F. Stocchi, M. F. De Pandis, G. Venturini and V. Margotta, "A Pharmacological Study of Cocaine Activity in Planaria,” Comparative Biochemistry and Physiology-Part C: Toxicology \& Pharmacology, Vol. 115, No. 1, 1996, pp. 41-45. doi:10.1016/S0742-8413(96)00053-9

[46] F. Passarelli, A. Merante, F. E. Pontieri, V. Margotta, G. Venturini and G. Palladini, "Opioid-Dopamine Interaction in Planaria: A Behavioral Study," Comparative Bio- 
chemistry and Physiology-Part C: Toxicology \& Pharmacology, Vol. 124, No. 1, 1999, pp. 51-55. doi:10.1016/S0742-8413(99)00048-1

[47] P. Ribeiro, F. El-Shehabi and N. Patocka, “Classical Transmitters and Their Receptors in Flatworms,” Parasitology, Vol. 131, Suppl. 1, 2005, pp. S19-S40.

[48] G. Venturini, A. Carolei, G. Palladini, V. Margotta and M. G. Lauro, "Radioimmunological and Immunocyto-Chemical Demonstration of Met-Enkephalin in Planaria,” Comparative Biochemistry and Physiology Part C: Comparative Pharmacology, Vol. 74, No. 1, 1983, pp. 23-25. doi:10.1016/0742-8413(83)90141-X

[49] G. Venturini, F. Stocchi, V. Margotta, S. Ruggieri, D. Bravi, P. Bellantuono and G. Palladini, “A Pharmacological Study of Dopaminergic Receptors in Planaria,” Neuropharmacology, Vol. 28, No. 12, 1989, pp. 1377-1382. doi:10.1016/0028-3908(89)90013-0

[50] J. H. Welsh and L. D. Williams, "Monoamine-Containing Neurons in Planaria," The Journal of Comparative Neurology, Vol. 138, No. 1, 1970, pp. 103-115. doi:10.1002/cne.901380108

[51] R. B. Raffa and P. Desai, "Description and Quantification of Cocaine Withdrawal Signs in Planaria,” Brain Research, Vol. 1032, No. 1-2, 2005, pp. 200-202. doi:10.1016/j.brainres.2004.10.052

[52] R. B. Raffa, K. E. Finno, C. S. Tallarida and S. M. Rawls, "Topiramate-Antagonism of L-Glutamate-Induced Paroxysms in Planarians,” European Journal of Pharmacology, Vol. 649, No. 13, 2010, pp. 150-153. doi:10.1016/j.ejphar.2010.09.021

[53] R. B. Raffa, L. J. Holland and R. J. Schulingkamp, "Quantitative Assessment of Dopamine D2 Antagonist Activity Using Invertebrate (Planaria) Locomotion as a Functional Endpoint," Journal of Pharmacological and Toxicological Methods, Vol. 45, No. 3, 2001, pp. 223-226. doi:10.1016/S1056-8719(01)00152-6

[54] R. B. Raffa and A. F. Martley, “Amphetamine-Induced Increase in Planarian Locomotor Activity and Block by UV Light,” Brain Research, Vol. 1031, No. 1, 2005, pp. 138-140. doi:10.1016/j.brainres.2004.10.051

[55] R. B. Raffa and S. M. Rawls, "Planaria: A Model for Drug Action and Abuse,” Landes Bioscience, Inc., Austin, 2008.

[56] R. B. Raffa, M. J. Robinson and R. J. Tallarida, "Ultraviolet Light-Induced Photorelaxation of Agonist-Contracted Rabbit Aorta: Further Characterization and the Estimation of Drug-Receptor Rate Constants,” Drug Development Research, Vol. 5, No. 4, 1985, pp. 359-369. doi:10.1002/ddr.430050409

[57] R. B. Raffa, G. W. Stagliano and S. Umeda, "KappaOpioid Withdrawal in Planaria," Neuroscience Letters, Vol. 349, No. 3, 2003, pp. 139-142. doi:10.1016/S0304-3940(03)00814-0

[58] R. B. Raffa and J. M. Valdez, "Cocaine Withdrawal in Planaria,” European Journal of Pharmacology, Vol. 430, No. 1, 2001, pp. 143-145. doi:10.1016/S0014-2999(01)01358-9

[59] R. B. Raffa, J. M. Valdez, L. J. Holland and R. J. Schulingkamp, "Energy-Dependent UV Light-Induced Disrup- tion of (-)Sulpiride Antagonism of Dopamine,” European Journal of Pharmacology, Vol. 406, No. 3, 2000, pp. R11-R12. doi:10.1016/S0014-2999(00)00730-5

[60] S. M. Rawls, T. Thomas, M. Adeola, T. Patil, N. Raymondi, A. Poles, M. Loo and R. B. Raffa, "Topiramate Antagonizes NMDA- and AMPA-Induced Seizure-Like Activity in Planarians," Pharmacology Biochemistry and Behavior, Vol. 93, No. 4, 2009, pp. 363-367. doi:10.1016/j.pbb.2009.05.005

[61] S. Umeda, G. W. Stagliano and R. B. Raffa, "Cocaine and Kappa-Opioid Withdrawal in Planaria Blocked by D-, but Not L-, Glucose,” Brain Research, Vol. 1018, No. 2, 2004, pp. 181-185. doi:10.1016/j.brainres.2004.05.057

[62] D. Bian, M. H. Ossipov, M. Ibrahim, R. B. Raffa, R. J. Tallarida, T. P. Malan, Jr., J. Lai and F. Porreca, "Loss of Antiallodynic and Antinociceptive Spinal/Supraspinal Morphine Synergy in Nerve-Injured Rats: Restoration by MK-801 or Dynorphin Antiserum,” Brain Research, Vol. 831, No. 1, 1999, pp. 55-63. doi:10.1016/S0006-8993(99)01393-1

[63] E. A. Bolan, R. J. Tallarida and G. W. Pasternak, "Synergy between $\mathrm{Mu}$ Opioid Ligands: Evidence for Functional Interactions among $\mathrm{Mu}$ Opioid Receptor Subtypes," Journal of Pharmacology and Experimental Therapeutics, Vol. 303, No. 2, 2002, pp. 557-562. doi:10.1124/jpet.102.035881

[64] E. E. Codd, R. P. Martinez, L. Molino, K. E. Rogers, D. J. Stone and R. J. Tallarida, "Tramadol and Several Anticonvulsants Synergize in Attenuating Nerve Injury-Induced Allodynia,” Pain, Vol. 134, No. 3, 2008, pp. 254262. doi:10.1016/j.pain.2007.04.019

[65] C. A. Fairbanks, K. F. Kitto, H. O. Nguyen, L. S. Stone and G. L. Wilcox, "Clonidine and Dexmedetomidine Produce Antinociceptive Synergy in Mouse Spinal Cord," Anesthesiology, Vol. 110, No. 3, 2009, pp. 638-647. doi:10.1097/ALN.0b013e318195b51d

[66] M. J. Field, M. I. Gonzalez, R. J. Tallarida and L. Singh, "Gabapentin and the Neurokinin(1) Receptor Antagonist CI-1021 Act Synergistically in Two Rat Models of Neuropathic Pain,” Journal of Pharmacology and Experimental Therapeutics, Vol. 303, No. 2, 2002, pp. 730-735. doi:10.1124/jpet.102.033134

[67] D. Mukherjee, S. E. Nissen and E. J. Topol, "Risk of Cardiovascular Events Associated with Selective COX-2 Inhibitors," JAMA: The Journal of the American Medical Association, Vol. 286, No. 8, 2001, pp. 954-959. doi:10.1001/jama.286.8.954

[68] R. B. Raffa, D. J. Stone, Jr. and R. J. Tallarida, "Discovery of 'Self-Synergistic' Spinal/Supraspinal Antinociception Produced by Acetaminophen (Paracetamol)” Journal of Pharmacology and Experimental Therapeutics, Vol. 295, No. 1, 2000, pp. 291-294.

[69] R. B. Raffa, R. Clark-Vetri, R. J. Tallarida and A. I. Wertheimer, "Combination Strategies for Pain Management," Expert Opinion on Pharmacotherapy, Vol. 4, No. 10, 2003, pp. 1697-1708. doi:10.1517/14656566.4.10.1697

[70] D. W. Kolpin, E. T. Furlong, M. T. Meyer, E. M. Thurman, S. D. Zaugg, L. B. Barber and H. T. Buxton, "Pharmaceuticals, Hormones, and Other Organic Waste-Water 
Contaminants in US Streams, 1999-2000: A National Reconnaissance,” Environmental Science \& Technology, Vol. 36, No. 6, 2002, pp. 1202-1211. doi:10.1021/es011055j

[71] P. E. Stackelberg, E. T. Furlong, M. T. Meyer, S. D. Zaugg, A. K. Henderson and D. B. Reissman, "Persistence of Pharmaceutical Compounds and Other Organic Wastewater Contaminants in a Conventional Drinking-WaterTreatment Plant," Science of the Total Environment, Vol. 329, No. 1, 2004, pp. 99-113. doi:10.1016/j.scitotenv.2004.03.015

[72] K. A. Kidd, P. J. Blanchfield, K. H. Mills, V. P. Palace, R. E. Evans, J. M. Lazorchak and R. W. Flick, "Collapse of a Fish Population after Exposure to a Synthetic Estrogen," Proceedings of the National Academy of Sciences of the United States, Vol. 104, No. 21, 2007, pp. 8897-8901. doi:10.1073/pnas.0609568104

[73] M. E. Ortiz-Santaliestra, M. J. Fernandez-Beneitez, M. Lizana and A. Marco, "Influence of a Combination of Agricultural Chemicals on Embryos of the Endangered Gold-Striped Salamander (Chioglossa lusitanica)," Archives of Environmental Contamination and Toxicology, Vol. 60, No. 4, 2011, pp. 672-680. doi:10.1007/s00244-010-9570-X
[74] R. A. Relyea and N. Mills, "Predator-Induced Stress Makes the Pesticide Carbaryl More Deadly to Gray Tree Frog Tadpoles (Hyla versicolor)," Proceedings of the National Academy of Sciences of the United States, Vol. 98, No. 5, 2001, pp. 2491-2496. doi:10.1073/pnas.031076198

[75] M. D. Boone, C. M. Bridges, J. F. Fairchild and E. E. Little, "Multiple Sublethal Chemicals Negatively Affect Tadpoles of the Green Frog, Rana Clamitans," Environmental Toxicology and Chemistry, Vol. 24, No. 5, 2005, pp. 1267-1272. doi:10.1897/04-319R.1

[76] M. D. Boone, R. D. Semlitsch, E. E. Little and M. C. Doyle, "Multiple Stressors in Amphibian Communities: Effects of Chemical Contamination, Bullfrogs, and Fish," Ecological Applications, Vol. 17, No. 1, 2007, pp. 291-301. doi:10.1890/1051-0761(2007)017[0291:MSIACE]2.0.CO ;2

[77] P. T. Johnson, E. R. Preu, D. R. Sutherland, J. M. Romansic, B. Han and A. R. Blaustein, "Adding Infection to Injury: Synergistic Effects of Predation and Parasitism on Amphibian Malformations,” Ecology, Vol. 87, No. 9, 2006, pp. 2227-2235. doi:10.1890/0012-9658(2006)87[2227:AITISE]2.0.CO;2 